\title{
Production of Bioactive Compounds by Bacillus subtilis against Sclerotium rolfsii
}

\author{
Nalisha, I. ${ }^{*}$, Muskhazli, M. and Nor Farizan, T. \\ Biology Department, Faculty of Science, Universiti Putra Malaysia, 43400 Serdang, Selangor. \\ E-mail: nalisha_ithnin@hotmail.com
}

\begin{abstract}
This study aims to investigate the characteristic of bioactive compound produced by Bacillus subtilis against Sclerotium rolfsii and the influence of additive supplements on the antagonistic activity of $B$. subtilis. The fact that $B$. subtilis produced an antifungal substance which has inhibitory effect on wide range of fungi, including $S$. rolfsii, is well known. To learn the effect of $\mathrm{pH}$, temperature and light condition on the production of antifungal compound, $B$. subtilis was inoculated in Potato Dextrose Broth at various initial $\mathrm{pH}$, temperatures and light conditions, respectively. This antagonist was found to produce antifungal compound that stable at $80^{\circ} \mathrm{C}$ with $58.3 \%$ inhibition on $S$. rolfsii. The activity was constant within a wide range of $\mathrm{pH}(3-11)$. However, treatment with $\mathrm{pH} 11$ lead to higher antifungal activity (31.57 \% inhibition) and it was also found to produce substance that can endure dark condition (46.24\% inhibition) with fungicidal effect on $S$. rolfsii. A series of experiments also been carried out to enhance the antifungal production by supplementing different carbon source preparation into bacterial liquid culture. B. subtilis were grown in minimal medium containing $1 \%$ of oil palm root, Ganoderma lucidum or chitin, respectively prior to bioassay. Crude culture from oil palm root supplemented culture shown significantly reduction in $S$. rolfsii growth compared to other carbon source crude culture or the antagonism alone, suggesting that this approach may provide improved biocontrol efficiency.
\end{abstract}

Keyword: Bacillus subtilis , Sclerotium rolfsii, antifungal activity, carbon source

\section{INTRODUCTION}

Recognizing the hazards of fungicides and pesticides to man and the environment, many countries in the world today is considering biological control as the best alternative to chemical control of plant diseases and pests (Souto et al., 2004). There were several reports on Bacillus subtilis potential as biological control agent against plant pathogenic fungi and bacteria (Ferreira et al., 1991). In other previous work, B. subtilis was able to reduce the incidence of bean rust caused by Uromyces appendiculatus up to $74 \%$ under field conditions (Baker and Cook, 1982). It has also been reported that some Bacillus strains showed significant inhibition activity against Botrytis cinerea (Walker et al., 1998), Puccinia pelargonii-zonalis germination (Rytter et al., 1989) and Fusarium oxysporum (Lang et al., 2002) under greenhouse experiments.

The proposed mechanisms resulting in biocontrol are competition for substrate (Sivan and Chet, 1989), ability to colonize the niche favored by the pathogen, antagonism by antibiotics, antibiosis (McKeen et al., 1986) and action of cell-wall degrading enzymes (Chet et al., 1998). Fiddaman and Rossall (1993) had suggested that another potential mode of action may lie with the production of antifungal metabolites. In this study, $B$. subtilis was discovered to produce antifungal compound which was antagonistic to the growth of $S$. rolfsii. Therefore this study aims to investigate the characteristic of bioactive compound produced by Bacillus subtilis against Sclerotium rolfsii and the influence of additive

\section{${ }^{*}$ Corresponding author}

supplements on the antagonistic activity of $B$. subtilis.

\section{MATERIALS AND METHOD}

\section{Microorganisms and Culture Condition}

For these studies Bacillus subtilis obtained from Department of Biology Culture Collection, Universiti Putra Malaysia and Sclerotium rolfsii from Agriculture Faculty, Universiti Putra Malaysia were used. Both B. subtilis and S. rolfsii were maintained on nutrient Agar (NA) and Potato Dextrose Agar (PDA) slants, respectively and stored at room temperature $\left(28^{\circ} \mathrm{C} \pm 2\right)$.

\section{Carbon Source Preparation}

Oil palm root and basidiocarp of Ganoderma lucidum were collected from Taman Pertanian Universiti, UPM. Samples were oven dried $\left(60^{\circ} \mathrm{C}\right)$ before grinded to powder form and kept for further use in air tight container. Chitin powder was purchased from Sigma-Aldwich.

\section{Minimal Media Preparation}

Forty flasks each containing $25 \mathrm{ml}$ of Minimal Media $(0.1$ $\%(\mathrm{w} / \mathrm{v}) \mathrm{KH}_{2} \mathrm{PO}_{4}$ and $0.05 \%(\mathrm{w} / \mathrm{v}) \mathrm{MgSO}_{4} .7 \mathrm{H}_{2} \mathrm{O}$ ) were then added with $1 \%(\mathrm{w} / \mathrm{v})$ palm oil root, Ganoderma lucidum or chitin respectively, before been autoclaved at $121^{\circ} \mathrm{C}$ for 15 minutes and added with $1 \times 10^{7} \mathrm{cell} / \mathrm{ml}$ of $B$. subtilis stock. The cultures were incubated for $96 \mathrm{~h}$ and agitated on rotary shaker at $140 \mathrm{rpm}$ at $28^{\circ} \mathrm{C}$. Samples were harvested every $12 \mathrm{~h}$, filtered through Whatman 
Paper No.1 before re-filtered using $0.2 \mathrm{~m}$ cellulose acetate filter and freeze-dried for further use.

\section{Bioassay Test}

Tests were conducted to distinguish the efficiency of the bacterial isolates in inhibiting growth of Sclerotium rolfsii. For this, dual culture system was carried out as described by Kobayashi et al. (2000). Antagonistic activities were assessed every $12 \mathrm{~h}$ for 4 days after incubation by measuring the radius of the pathogen colony in direction of the bacterial colony and the radius of the pathogen colony in the control plate. The readings were then transformed into percentage, where higher percentage indicates greater ability of the bacteria to inhibit the growth of the pathogen.

\section{Stability Test}

Stability test of a range of $\mathrm{pH}(3,5,7,9,11)$, temperature $\left(-20,4,28,80,100^{\circ} \mathrm{C}\right)$ and light condition (light, dark, UV) were carried out as suggested by Yu et al. (2002).

\section{Agar Diffusion Assay}

Bacillus crude culture used in this assay was prepared using minimal media as describe previously. The concentrated preparation of metabolites was tested for antifungal activity. Method by Walker et al. (1998) was used in order to assess antifungal activity for different carbon source treatments by measuring the radius of the zones of inhibition. In each well, crude culture was applied randomly and the plates were incubated at room temperature $\left(28^{\circ} \mathrm{C} \pm 2\right)$ for 4 days.

\section{RESULTS AND DISCUSSION}

Two separate bioassay tests (application of $B$. subtilis alone and combined with carbon source) were conducted to assess antifungal activity against pathogen. However, the degree of inhibition varies between the first and the second experiment. The readings obtained were then transformed into percentage to indicate the ability of the bacteria to inhibit the growth of the pathogen. Bacillus was found to subdue $S$. rolfsii growth, up to $13.05 \%$, based on the percentage of growth analysis; thus indicating that $S$. rolfsii was sensitive towards Bacillus secretions. Summary of the results were shown Table 1. This finding was similar to the test conducted by Souto et al. (2004), where mycelia growth of Sclerotium sp. was inhibited by application of Bacillus sp. using the dual culture technique. When Sclerotium sp. was challenged with the Bacillus sp. culture, growth inhibition of mycelia occurred accompanied by a decreased sclerotia production. Application of other biological control agent such as Trichoderma koningii (Tsahouridou and Thanassoulopoulos, 2002), T. harzianum (Lima et al., 1999) and Serratia marcescen (Ordentlich et al., 1987) were also found to be effective in controlling $S$. rolfsii via secretion of chitinase.
Table 1: Inhibition (\%) of Sclerotium rolfsii after tested against Bacillus subtilis.

\begin{tabular}{cccc}
\hline $\begin{array}{c}\text { Incubation } \\
\text { period (h) }\end{array}$ & $\begin{array}{c}\text { Growth without } \\
\text { Bacillus subtilis } \\
(\mathbf{c m})\end{array}$ & $\begin{array}{c}\text { Growth with } \\
\text { Bacillus } \\
\text { subtilis }(\mathbf{c m})\end{array}$ & $\begin{array}{c}\text { Percentage } \\
\text { of inhibition } \\
(\%)\end{array}$ \\
\hline 12 & 0.8 & 0.8 & 0 \\
24 & $2.384 \pm 0.084$ & $2.269 \pm 0.1$ & $4.82 \pm 0.13$ \\
36 & $3.704 \pm 0.059$ & $3.431 \pm 0.06$ & $7.36 \pm 1.52$ \\
48 & $5.060 \pm 0.041$ & $4.636 \pm 0.08$ & $8.38 \pm 1.57$ \\
60 & $6.540 \pm 0.086$ & $6.001 \pm 0.07$ & $8.24 \pm 1.76$ \\
72 & $7.556 \pm 0.054$ & $6.570 \pm 0.09$ & $13.05 \pm 1.09$ \\
84 & $7.684 \pm 0.010$ & $7.025 \pm 0.01$ & $8.58 \pm 0.98$ \\
\hline
\end{tabular}

Note:Values are percentage of inhibition \pm SD $(n=7)$. Means in a column with the same superscript are not significantly different $(p>0.05)$. nd - Not detected

When culture filtrates were given direct sunlight and dark treatments, reduction of diameter as high as $38.36 \%$ and $46.24 \%$, respectively, can be seen (Table 2). However, when exposed to UV condition the inhibition is vaguely lower $(25.65 \%)$. The reduction in the inhibition activity caused by the radiation emitted could have caused alteration in the antifungal compounds structure thus prevent $B$. subtilis from performing at their optimal performance (Tortora et al., 1997). This were consistent with the study by Papavizas and Lewis (1983) where Trichoderma spp. induced by UV showed different ability to suppress damping off caused by $P$. ultimum and $R$. solani and therefore suggested long exposure to UV radiation to induce new and stable Trichoderma spp.. Neither direct light nor UV had altered the antifungal activity of each culture filtrates as microorganisms are able to repair damage and alterations induced to their DNA by UV treatment following the administration of a sub-lethal dose (Hassen et al., 2000). Hassen et al. (2000) also reported some classified microorganisms and their propagules in the following increasing order of resistance to UV treatment: bacteria < viruses < fungi < spores <cysts.

The antifungal compounds were also remarkably thermo stable. Heat/temperature treatment showed no alteration in the inhibition activity of the culture filtrates even after treated at $100^{\circ} \mathrm{C}(46.53 \%)$. The antifungal activity can be detected throughout the study and this showed that different treatment of heat and temperatures would not completely destroy the antifungal compound. More than $50 \%$ of inhibition was detected when crude culture was place at $80^{\circ} \mathrm{C}$. This finding was similar to the report by Shoda (2000) on the special characteristics of Bacillus which is high thermal tolerance, rapid growth in liquid culture and ready formation of resistant spores. Cléry-Barraud et al. (2004) in their study on inactivation of Bacillus anthracis spore using heat and pressure, also proved that spores of $B$. anthracis are extremely resistant 
Table 2: Inhibition (\%) of Sclerotium rolfsii in the presence of Bacillus subtilis culture filtrate after treated with different heat, $\mathrm{pH}$ and light conditions.

\begin{tabular}{|c|c|c|c|c|c|c|c|}
\hline \multirow{2}{*}{\multicolumn{2}{|c|}{ Treatment }} & \multicolumn{6}{|c|}{ Hour } \\
\hline & & 24 & 36 & 48 & 60 & 72 & 84 \\
\hline \multirow{5}{*}{$\begin{array}{l}\text { Heat } \\
\left({ }^{\circ} \mathrm{C}\right)\end{array}$} & -20 & $57.16 \pm 1.13^{\mathrm{a}}$ & $52.02 \pm 0.46^{a}$ & $31.89 \pm 1.12^{b}$ & $26.08 \pm 1.06^{b}$ & $21.88 \pm 0.71^{a}$ & $7.96 \pm 0.43^{a}$ \\
\hline & 4 & $21.65 \pm 1.82^{\mathrm{C}}$ & $-3.66 \pm 2.55^{d}$ & $-7.13 \pm 2.07^{e}$ & $4.28 \pm 1.23^{d}$ & nd & nd \\
\hline & 28 & $4.82 \pm 2.08^{d}$ & $7.36 \pm 3.27^{c}$ & $8.38 \pm 2.47^{d}$ & $8.24 \pm 2.58^{c}$ & $13.05 \pm 1.94^{b}$ & $7.68 \pm 0.04^{a}$ \\
\hline & 80 & $58.30 \pm 2.09^{a}$ & $52.24 \pm 3.33^{a}$ & $38.19 \pm 2.52^{\mathrm{a}}$ & $30.54 \pm 2.55^{\mathrm{a}}$ & $20.82 \pm 1.87^{a}$ & nd \\
\hline & 100 & $46.53 \pm 3.72^{b}$ & $23.00 \pm 3.14^{b}$ & $12.18 \pm 1.33^{\mathrm{C}}$ & $9.70 \pm \mathrm{c} 1.53^{\mathrm{c}}$ & $13.60 \pm 0.86^{b}$ & $7.68 \pm 0.03^{a}$ \\
\hline \multirow{5}{*}{$\mathrm{pH}$} & 3 & $-15.88 \pm 3.51^{i}$ & $-20.15 \pm 2.12^{h}$ & $-13.85 \pm 1.53^{i}$ & $2.76 \pm 1.36^{i}$ & $7.85 \pm 0.65^{h, i}$ & nd \\
\hline & 5 & $28.33 \pm 2.98^{f}$ & $7.92 \pm 2.13^{g}$ & $15.15 \pm 1.52^{f}$ & $16.09 \pm 0.94^{f}$ & $17.46 \pm 1.01^{f}$ & $8.02 \pm 0.73$ \\
\hline & 7 & $-4.66 \pm 2.91^{\mathrm{h}}$ & $-19.30 \pm 1.67^{h}$ & $-12.91 \pm 1.86^{i}$ & $3.14 \pm 1.44^{i}$ & $9.85 \pm 0.93^{g}$ & nd \\
\hline & 9 & $-3.34 \pm 4.11^{\mathrm{h}}$ & $-18.23 \pm 2.28^{h}$ & $-6.21 \pm 1.93^{h}$ & $6.37 \pm 1.17^{\mathrm{h}}$ & $8.60 \pm 1.07^{\mathrm{h}}$ & nd \\
\hline & 11 & $10.96 \pm 2.63^{g}$ & $31.57 \pm 1.88^{f}$ & $11.09 \pm 1.13^{g}$ & $14.32 \pm 1.72^{\mathrm{g}}$ & $7.09 \pm 0.55^{i}$ & nd \\
\hline \multirow[t]{3}{*}{ Light } & Light & $38.36 \pm 3.41^{\prime}$ & $35.75 \pm 1.84^{k}$ & $28.75 \pm 2.33^{k}$ & $25.54 \pm 1.74^{k}$ & $21.58 \pm 1.07^{k}$ & $8.21 \pm 0.72^{k}$ \\
\hline & Dark & $46.24 \pm 2.53^{k}$ & $37.71 \pm 2.76^{k}$ & $28.62 \pm 2.03^{k}$ & $24.67 \pm 0.62^{k}$ & $13.91 \pm 0.93^{\prime}$ & nd \\
\hline & UV & $25.65 \pm 2.74^{m}$ & $20.87 \pm 3.17^{\prime}$ & $25.54 \pm 3.28^{\prime}$ & $24.62 \pm 1.34^{k}$ & $22.10 \pm 0.84^{k}$ & $8.02 \pm 0.44^{k}$ \\
\hline
\end{tabular}

Note: Values are percentage of inhibition \pm SD $(n=7)$. Means in a column with the same superscript are not significantly different $(p>0.05)$. nd - Not detected

to heat treatment, irradiation, desiccation, and disinfectants. Furthermore, it have been suggested that the resistance of growing cells to heat stress was mainly caused by heat shock protein which plays a major role to form a heat resistance spore (Hecker et al., 1996).

$B$. subtilis culture filtrates are also not influenced by variation of $\mathrm{pH}$ and had shown tolerance to wide $\mathrm{pH}$ range in the initial $\mathrm{pH}$ of the culture medium. Treatment with various $\mathrm{pH}$ showed different level of antifungal activity, with the lowest inhibition recorded when treated with $\mathrm{pH} 3$ $(2.76 \%)$ and highest when treated with $\mathrm{pH} 11$ (31.57\%). Though $\mathrm{pH}$ treatment managed to alter the production of Bacillus antifungal activity against pathogen (Wang et al., 2002), Silo-Suh et al. (1994) proved that Bacillus cereus UW85 managed to subdue damping-off of alfalfa caused by Phytophthora medicaginis at $\mathrm{pH} 7$. Therefore, the antifungal activity produced in this study can be classified as different from the one being described by Wang et al. (2002) as the activities were not totally destroyed by very acidic treatments. Nicholson et al. (2000) suggest that in order to maintain the potential for spore viability, the spore must either (i) Prevent damage which would inactivate critical cellular components needed for successful germination and resumption of growth or (ii) Repair or replace those damaged critical components during germination, before their inactivation results in cell death.
Since the treatment given can damage proteins as well as DNA, it is possible that repair of protein damage during spore germination and outgrowth plays a role in resistance of spores (Setlow, 1995).

Bacillus was able to grow on all carbon sources tested with significant different antifungal production as in Table 3 (ANOVA, $\mathrm{p}<0.05$ ). Among several carbon sources, the maximum growth of bacterium and $\beta$ glucanase production was obtained with lactose as sole carbon source (Usama, 2003). When $1 \%$ palm oil root was used as carbon source, inhibition zone reached it maximum of $2.93 \mathrm{~cm}$ in diameter after $36 \mathrm{~h}$; meanwhile by using G. lucidum, the maximum inhibition zone reached after $12 \mathrm{~h}$ was $2.84 \mathrm{~cm}$. Moreover, additional of $1 \%$ chitin revealed inhibition area of $2.85 \mathrm{~cm}$ more compared to the bioassay test conducted earlier after $12 \mathrm{~h}$ incubation. Results (Figure 1) showed antifungal compound was more induced after $36 \mathrm{~h}(32.38 \%)$ when cells were grown in media containing oil palm root preparation.

The enhancement could have been due to nutritional factors acting as inducers, since additional carbon source led to an increased hydrolytic enzyme production which have been known to degrade fungal cell wall (Lang et al., 2002). Secondary products from higher plants represent an enormous diversity of biologically active compounds that can be exploited as pesticides, when plant residues 
decomposed are incorporated as green manure. These metabolites are usually produced inside plant tissue and can be released when plant debris is incorporated into the soil and subjected to microbial degradation (Gamliel et al., 2000). In addition, application of organic soil amendment may induce chemical and physical changes that also affect soil microflora. The presence of organic substances rich in cellulose was also shown to stimulate growth of organisms with cellulose activity (Elad et al., 1985).

Table 3: Inhibition (cm) of Sclerotium rolfsii in the presence of Bacillus subtilis culture filtrate supplemented with $1 \%(\mathrm{w} / \mathrm{v})$ carbon source.

\begin{tabular}{cccc}
\hline \multirow{2}{*}{$\begin{array}{c}\text { Incubation } \\
(\mathrm{h})\end{array}$} & \multicolumn{3}{c}{ Carbon Source } \\
\cline { 2 - 4 } & Oil palm root & $\begin{array}{c}\text { Ganoderma } \\
\text { lucidum }\end{array}$ & Chitin \\
\hline 12 & $2.43 \pm 0.07^{\mathrm{c}, \mathrm{d}}$ & $2.84 \pm 0.07^{\mathrm{e}}$ & $2.85 \pm 0.06^{\mathrm{f}}$ \\
24 & $2.55 \pm 0.09^{\mathrm{d}, \mathrm{e}}$ & $2.80 \pm 0.05^{\mathrm{e}}$ & $2.54 \pm 0.06^{\mathrm{e}}$ \\
36 & $2.93 \pm 0.07^{\mathrm{f}}$ & $2.28 \pm 0.05^{\mathrm{b}}$ & $2.39 \pm 0.04^{\mathrm{d}}$ \\
48 & $2.56 \pm 0.04^{\mathrm{d}, \mathrm{e}}$ & $2.58 \pm 0.08^{\mathrm{d}}$ & $2.27 \pm 0.05^{\mathrm{c}}$ \\
60 & $2.66 \pm 0.08^{\mathrm{d}, \mathrm{e}, \mathrm{f}}$ & $2.13 \pm 0.06^{\mathrm{a}}$ & $2.41 \pm 0.05^{\mathrm{d}}$ \\
72 & $2.42 \pm 0.05^{\mathrm{c}, \mathrm{d}}$ & $2.48 \pm 0.05^{\mathrm{c}}$ & $1.82 \pm 0.09^{\mathrm{a}}$ \\
84 & $2.82 \pm 0.05^{\mathrm{e}, \mathrm{f}}$ & $2.18 \pm 0.03^{\mathrm{a}}$ & $1.86 \pm 0.09^{\mathrm{a}, \mathrm{b}}$ \\
\hline
\end{tabular}

Note: Values are mean of inhibition $\pm \operatorname{SD}(n=7)$. Means in a column with the same superscript are not significantly different $(p>0.05)$.

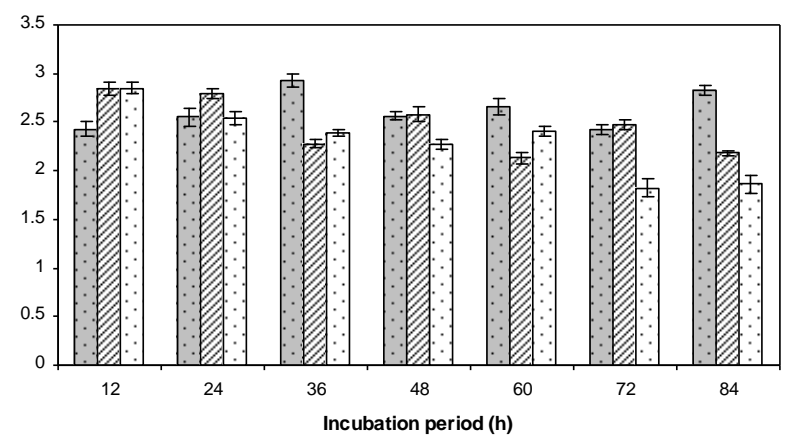

$\square$ Oil palm root $\square$ Ganoderma lucidum $\square$ Chitin

Figure 1: Diameter of inhibition (cm) of Sclerotium rolfsii after treated with Bacillus subtilis supplemented with $1 \%$ $(w / v)$ of various types of carbon sources.

\section{CONCLUSION}

Bacillus subtilis produced bioactive compound active against the plant pathogenic fungi, Sclerotium rolfsii. The metabolite excreted by $B$. subtilis remained active after treated with heat, resistant over a wide $\mathrm{pH}$ range and UV.
Application of additional carbon source did enhance the antifungal activity; with grinded oil palm root supplement showed highest antifungal activity (up to $40 \%$ inhibition).

\section{ACKNOWLEDGEMENTS}

The authors are indebted to Universiti Putra Malaysia (UPM) for their technical assistance and Ministry of Science, Technology and Innovation for the research funding under EA project (09-02-04-0667-EA001) for IRPA RM8.

\section{REFERENCES}

Baker, K.F. and Cook, R.J. (1982). Biological control of plant pathogens. The American Phytopathological Society, St. Paul, MN. p. 433.

Chet, I., Benhamou, N. and Haran, S. (1998). Trichoderma and Gliocladium. In: Harman, G.E. and Kubicek, C.P. (Eds). Mycoparasitism and lytic enzymes. Taylor and Francis. p. 153-172.

Cléry-Barraud, C., Gaubert, A., Masson, P. and Vidal, D. (2004). Combined effects of high hydrostatic pressure and temperature for inactivation of Bacillus anthracis spores. Applied and Environmental Microbiology 70: 635-637.

Elad, Y., Lifshitz, R. and Baker, R. (1985). Enzymatic activity of the mycoparasite Pythium nunn during interaction with host and non-host fungi. Physiology and Plant Pathology 27: 131-148.

Ferreira, J.H.S., Matther, F.N. and Thomas, A.C. (1991). Biological control of Euthypa lata on grapevine by an antagonistic strain of Bacillus subtilis. Phytopathology 81: 283-287.

Fiddaman, P.J. and Rossall, S. (1993). The production of antifungal volatiles by Bacillus subtilis. Journal of Applied Bacteriology 74: 119-126.

Gamliel, A., Austerweil, M. and Kritzman, G. (2000). Non-chemical approach to soilborne pest management-organic amendments. Crop Protection 19: 847-853.

Hassen, A., Mahrouk, M., Ouzari, H., Cherif, M., Boudabous, A. and Damelincourt, J.J. (2000). UV disinfection of treated wastewater in a large-scale pilot plant and inactivation of selected bacteria in a laboratory UV device. Bioresource Technology 74: 141-150.

Hecker, M., Schumann, W. and Volker, U. (1996). Heat shock and general stress response in Bacillus subtilis. Molecular Microbiology 19: 417-428.

Kobayashi, K., Gasoni, L., Vicario, A. and y Cozzi, J. (2000). Suppressive effects of antagonistic bacteria and metabolites on a pathogenic Rhizoctonia solani strain. Increased production in a specific medium. RIA 29: 63-76.

Lang, W.S., Shih, I.L., Wang, C.H., Tseng, K.C., Chang, W.T., Twu, Y.K., Ro, J.J. and Wang, C.L. (2002). Production of antifungal compounds from chitin by 
Bacillus subtilis. Enzyme and Microbial Technology 31: 321-328.

Lima, L.H.C., De Marco, J.L., Ulhoa, C.J. and Felix, C.R. (1999). Synthesis of a Trichoderma chitinase which affects the Sclerotium rolfsii and Rhizoctonia solani cell walls. Folia Microbiologica 44: 45-49.

McKeen, C.D., Reilly, C.C. and Pusey, P.L. (1986). Production and partial characterization of antifungal substances antagonistic to Monilinia fructicola from Bacillus subtilis. Phytopathology 76: 136-139.

Nicholson, W.L., Munakata, N., Horneck, G., Melosh, H.J. and Setlow, P. (2000). Resistance of Bacillus endospores to extreme terrestrial and extraterrestrial environments. Microbiology and Molecular Biology Reviews 64: 548-572.

Ordentlich, A., Elad, Y. and Chet, I. (1987). Rhizosphere colonization by Serratia mearcescens for the control of Sclerotium rolfsii. Soil Biology and Biochemistry 19: 747-751.

Papavizas, G.C. and Lewis, J.A. (1983). Physiological and biocontrol characteristics of stable mutants of Trichoderma viride resistance to MBC fungicides. Phytopathology 73: 407-411.

Rytter, J.L., Lukezic, F.L., Craig, R. and Moorman, G. (1989). Biological control of geranium rust by Bacillus subtilis. Phytopathology 79: 367-370.

Setlow, P. (1995). Mechanisms for the prevention of damage to DNA in spores of Bacillus species. Annual Review of Microbiology 49:29-54.

Shoda, M. (2000). Review: Bacterial control of plant diseases. Journal of Bioscience and Bioengineering 89: 515-521.

Silo-suh, L.A., Lethbridge, B.J., Raffel, S.J., He, H., Clardy, J. and Handelsman, J. (1994). Biological activites of two fungistatic antibiotics produced by Bacillus cereus UW85. Applied and Environmental Microbiology 60: 2023-2030.

Sivan, C.J. and Chet, I. (1989). Degradation of fungal cell walls by lytic enzymes of Trichoderma harzianum. Journal of Genetic Microbiology 135: 675-682.
Souto, G.I., Correa, O.S., Montecchia, M.S., Kerber, N.L., Pucheu, N.L., Bachur, M. and Garcia, A.F. (2004). Genetic and functional characterization of a Bacillus sp. strain excreting surfactin and antifungal metabolites partially identified as iturin-like compounds. Journal of Applied Microbiology 97: 1247-1256.

Tortora, G.J., Funke, B.R. and Case, C.L. (1997). Microbiology: An introduction. 6th edition. Addison Wesley Longman, Inc.

Tsahouridou, P.C. and Thanassoulopoulos, C.C. (2002). Proliferation of Trichoderma koningii in the tomato rhizosphere and the suppression of dampingoff by Sclerotium rolfsii. Soil Biology and Biochemistry 34: 767-776.

Usama, B., Hesham, E.E., Ismail, I.M.K., Hassan, M., Ewa, W. and Sawsan, A.E.G. (2003). $\beta$-glucanase production from genetically modified recombinant Escherichia coli: Effect of growth substrates and development of a culture medium in shake flask and stirred tank bioreactor. Process Biochemistry 39: 307313.

Walker, R., Powell, A.A. and Seddon, B. (1998). Bacillus isolates from the spermosphere of peas and dwarf French beans with antifungal activity against Botrytis cinerea and Pythium species. Journal of Applied Microbiology 84: 791-801.

Wang, S.L., Shih, I.L., Wang, C.H., Tseng, K.C., Chang, W.T., Twu, Y.K., Ro, J.J. and Wang, C.L. (2002). Production of antifungal compounds from chitin by Bacillus subtilis. Enzyme Microbial Technology 31: 321-328.

Yu, G.Y., Sinclair, J.B., Hartman, G.L. and Bertagnolli, B.L. (2002). Production of iturin A by Bacillus amyloliquefaciens suppressing Rhizoctonia solani. Soil Biology and Biochemistry 34: 955-963. 